\title{
Budget Deficits and Economic Growth: A Vector Error Correction Modelling of South Africa
}

\author{
Kagiso Molefe, Andrew Maredza \\ School of Economics \& Decision Science, North West University, South Africa, \\ edwardmolefe22@gmail.com, Andrew.Maredza@nwu.ac.za
}

\begin{abstract}
The primary motivation behind this study was to explore the consequential effects of budget deficit on South Africa`s economic growth. Six variables were used, namely: real GDP, budget deficit, real interest rate, labour, gross fixed capital formation and unemployment. The Vector Error Correction Model (VECM) was used to estimate the long-run equation and also measure the correction from disequilibrium of preceding periods. Using annual time series data spanning the period 1985 to 2015, empirical evidence from the study revealed that budget deficits and economic growth are inversely related. It was therefore concluded that high levels of budget deficit in South Africa have detrimental effects on the growth of the economy. The estimate of the speed of adjustment coefficient found in this study revealed that about 29 per cent of the variation in GDP from its equilibrium level is corrected within one year. The results obtained in this study are favourably similar to those in the literature and are also sustained by previous studies.
\end{abstract}

Keywords: Budget Deficit, Economic Growth, Real Interest Rate, Vector Error Correction Model, South Africa

\section{Introduction}

It is an ideal depiction of every country both advanced and emerging to realise equilibrium between government expenditure and government raised revenue. However, government expenditure on both goods and services and transfers is likely to exceed the available resource envelope or collected revenue. This is predominantly due to excessive reliance on government expenditure as a source of social security, improved standard of living conditions and expanded physical infrastructure. Therefore, the realization of budget stability remains a challenge more particularly in developing economies where government expenditure is regarded as an indispensable component of economic growth and development. According to Mashakada (2013), in most Africa countries and other emerging economies, high budget deficits are at the centre of macroeconomic adjustments due to the developing nature of their economies. South Africa like other developing countries such as Zimbabwe, Mozambique, and Democratic Republic of Congo has experienced budget deficits over several decades. The very same budget deficits have led to numerous economic challenges such as price volatilities, high interest rates, stumpy economic performance, worsened credit ratings and uncontrollable debt. According to Murwirapachena, Maredza and Choga (2013) the South African government has since 1980's embarked on enormous spending sprees in an attempt to accomplish Pareto efficiency. For instance, the 2015/2016 total consolidated government expenditure was estimated at R1.4 billion whilst the revenue raised only amounted to R1.2 billion translating to a deficit of -3.9 per cent as affirmed by National Treasury (2015).

However, in spite of the yearly budget deficit being incurred by the government of South Africa, there are yet some economic challenges that remain unsolved. These include high unemployment rate (which was reported at $25.5 \%$ by Statistics South Africa, poorly positioned and insufficient infrastructural facilities, increasing unsettled public sector wage bill, insufficient revenue generation capacity as well as uneven service delivery. This is a clear indication that the South African performance in recent years fall short of expectations compared to peer countries such as Brazil, Turkey and India. Consequently, the motivation for this study is to examine the effects of budget deficits and some selected macroeconomic variables on the economic growth of South Africa. This study is structured as follows: the next section analyse the theoretical aspects to budget deficits and economic growth. In the same section, relevant empirical studies underpinning the subject matter are reviewed. Section 3 presents the methodological framework of the study. Empirical findings of the study are reported and discussed in section 4 while section 5 presents conclusion and policy recommendation.

Budget deficits and economic growth in South Africa: Since the year 1985, South African fiscal trends have recorded substantial budget deficits accompanied by stagnated economic growth. According to the National Treasury (2011), high fiscal deficits in South Africa emerged predominantly due to high levels of 
unemployment and stumpy economic growth performance. The first highest budget deficit recorded by South Africa was -6.6 per cent in 1993 while GDP only grew by 1.2 per cent. One major reason adduced for this was the increasing expenditure in preparation for the first democratic elections in the country. Just a year into democratic government, the budget deficit slumped down to -4.6 per cent at the same time as GDP was growing by 3.4 per cent. This was a good indication that the new government of South Africa was taking a correct path in addressing the errors of past apartheid regime. The South African government continued being fiscally enthusiastic and dedicated to cautious fiscal reforms through the implementation of Growth, Employment and Redistribution policy (GEAR) in 1996. This policy initiative was aimed among others at reducing the overall budget deficits to 3 per cent, encouraging the government level of savings, and decreasing government consumption relative to gross domestic product. The policy assisted the government of South Africa in reducing budget deficits to -3.2 per cent in 1998 as reported by South Africa Reserve Bank (2013). However, the budget deficits were still above the anticipated 3 per cent as stipulated by the GEAR policy. During the same year of 1998, the GDP growth rate only grew by 0.5 per cent (see figure 1 below).

\section{Figure 1: Budget deficit and GDP growth trends in South Africa (1985 - 2015)}

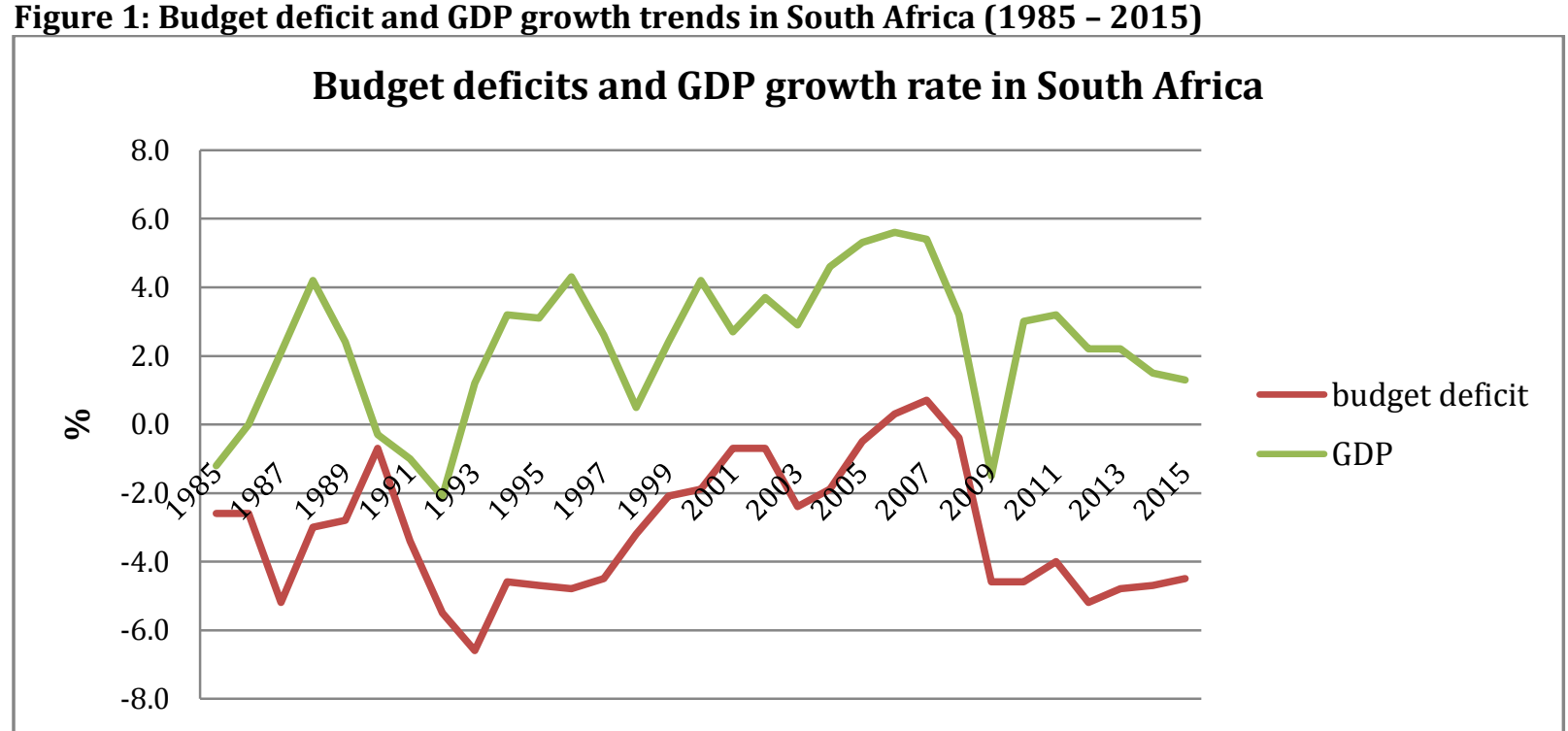

Source: author's own computation using data from World Bank

Based on figure 1 above, the highest GDP growth rate recorded by South Africa was 5.6 per cent and 5.4 per cent in 2006 and 2007 respectively. This was the same period South Africa recorded its first budget surpluses of 0.3 per cent and 0.7 per cent correspondingly. The budget surpluses were mainly due to large savings form debt servicing cost and under-spending by government departments. The reasonable expansionary monetary policy implemented by the South Africa Reserve Bank during that time also assisted the fiscal authorities in realising budget surpluses. The favourable economic conditions of that time assisted the government of South Africa in reducing the debt and also allowed expenditure redistribution. In the later stage of 2008 towards the beginning of 2009, the South African economy became hostile mainly due to the global economic meltdown. The magnitude of the global economic predicament on South African economy was enormous with budget deficits shifting from a surplus of 0.7 per cent to deficit of -4.6 per cent. Since then, the South African economy has been struggling to fully recover and this has positioned the country under fiscal constraint environment. According to the National Treasury (2015), the fiscal constraints facing the country has affected the swiftness and extent of government's contribution to the National Developmental Plan (NDP).

\section{Literature Review}

Empirical theoretical views on the relationship between budget deficits and economic growth can be traced back to the 1900s when Keynes (1936) endorsed government as a significant economic agent. According to Keynes, without government intervention an economy would fail as it was evident in the western industrialised world during the 1929-39 Great Depression. In a nutshell, Keynes believes that government 
should not be strained to present a balanced budget every financial year since this would weaken the role of taxation and transfers as stabilisers. However, with the commencement of the neoclassical theory, Diamond (1965) and Hubbard \& Judd (1986) dismissed the works of Keynes predominantly due to the fact that it supported budget deficits. The above-mentioned neoclassical theorists pointed out with great emphasis that continual government deficits results in crowding out of private capital accumulation. In support, Kotlikoff (1986) also argued strongly that budget deficits have diminutive effects on economic performance of the country. The above-mentioned theories led to the formation of the fiscal theory by Barro (1989) who strongly believed that deficit financing is just a postponement of future taxation. According to Barro (1989), the deficit in any present period is precisely equivalent to the current worth of forthcoming taxation that is compulsory to settle off the augmentation of debt resulting from deficit. Given the reason that there existed no coherent finding regarding the relationship between budget deficits and economic growth, a wide range of empirical studies have been carried out by different authors and various results were obtained. According to Fatima, Ahmed \& Rehman (2012) and Ezeabasili, Tsegba \& Ezi-herbert (2012) budget deficits are detrimental to economic growth whilst Eminer (2015) and Odhiambo, Momayi, Lucas \& Aila (2013) found budget deficits to be growth enhancing. In South Africa reviewing existing literature with regards to the relationship between budget deficits and economic growth remains a vast challenge. However fewer researchers including Murwirapachena, Maredza and Choga (2013), Biza, Kapingura \& Tsegaye (2015), Mujuta (2013) as well as Bonga-Bonga (2011) conducted studies to examine the effect of budget deficits on South Africa's economic growth and other macroeconomic variables. Both researchers concluded that budget deficits are not desirable for South African economy and as a result, government must apply expenditure ceiling and improve the taxation system to find sense of balance between government expenditure and revenue collected through taxation.

\section{Methodology}

This study employs the Vector Error Correction Model (VECM) to examine the consequential effect of budget deficits on economic growth of South Africa. Techniques such as the Augmented Dickey-Fuller (ADF) and the Phillip-Perron (PP) are performed to assess stationarity or the order of integration on the variables employed. If variables are found to be integrated at the same order I (1), then the study will proceed to test the long-run economic equilibrium correlation using the Johansen $(1991,1995)$ Maximum-Likelihood cointegration test. Afterwards, a VECM will be employed to estimate the long-run equation and the existence of the error correction. To ensure the goodness of fit of the model, the study will conduct the diagnostic checks and further perform the General Impulsive Response Function and the Variance Decomposition to examine how GDP respond to shocks coming from budget deficits and other selected economic variables.

Empirical model specification: To analyse the relationship between budget deficits and economic growth in South Africa, the study adopted the model used by Aslam (2016) in Sri Lanka. The model can be expressed in functional form as follows: $G D P=f(B D I F, R I R, L A B, G F C F, U N)$

Using the VAR Framework stochastic model of regression analysis, the model can then be specified as follows: $G D P=\delta_{0}+\delta_{1} B D I F+\delta_{2} R I R+\delta_{3} L A B+\delta_{4} G F C F+\delta_{5} U N+\mu_{t}$

Where:

GDP = Gross domestic product,

BDIF = Budget deficits,

RIR = Real interest rate,

$\mathrm{LAB}=$ Total labour force,

GFCF = Gross fixed capital formation,

UN = Total Unemployment, and

$\mu_{t} \quad=$ Error term.

This study included quite number of variables that have influence over GDP in order to avoid the problem of misspecification. Since variables are expressed in percentages, they are not transformed into logarithm. The model in (equation 2) can be converted to a VEC form as follows:

$$
\Delta G D P_{t}=\delta_{0}+\delta_{1} \Delta B D I F_{t-1}+\delta_{2} \Delta R I R_{t-1}+\delta_{3} \Delta L A B_{t-1}+\delta_{4} \Delta G F C F_{t-1}+\delta_{5} \Delta U N_{t-1}+\xi_{t-1}+\mu_{t} \cdots \cdots
$$


Where:

$\Delta \quad=$ difference operatives

$\xi_{t-1} \quad=$ lagged significance of error term.

Data analysis: All variables used in this study except GDP are derived from World Bank dataset. The variable GDP is derived from South African Reserve Bank Macroeconomic dataset. This data is tested for stationarity to avoid producing nonsensical or spurious results. The ADF and the PP techniques are employed at first difference and the results are presented in Table 1 and 2.

Table 1: Augmented Dickey-Fuller test results

\begin{tabular}{|c|c|c|c|c|}
\hline Variables & Model & t-value (lags) & $\begin{array}{l}5 \% \\
\text { Value }\end{array}$ & $\begin{array}{l}\text { Order of } \\
\text { integration }\end{array}$ \\
\hline GDP & Trend \& intercept & $-5.232(0)$ & $-3.644 * * *$ & I (1) \\
\hline BDIF & Trend \& intercept & $-4.988(0)$ & $-3.574 * * *$ & I (1) \\
\hline RIR & Trend \& intercept & $-7.215(0)$ & $-3.574 * * *$ & I (1) \\
\hline LAB & Trend \& intercept & $-3.786(0)$ & $-3.574^{* * *}$ & I (1) \\
\hline GFCF & Trend \& intercept & $-6.166(3)$ & $-3.595^{* * *}$ & I (1) \\
\hline UN & Trend \& intercept & $-4.659(0)$ & $-3.574 * * *$ & I (1) \\
\hline
\end{tabular}

Table 2: Phillip-Perron test results

\begin{tabular}{lllll}
\hline Variables & Model & t-value (lags) & $\begin{array}{l}\mathbf{5 \%} \text { critical } \\
\text { Value }\end{array}$ & $\begin{array}{l}\text { Order of } \\
\text { integration }\end{array}$ \\
\hline GDP & Trend \& intercept & $-5.232(0)$ & $-3.644^{* * *}$ & $\mathrm{I}(1)$ \\
BDIF & Trend \& intercept & $-4.988(0)$ & $-3.574^{* * *}$ & $\mathrm{I}(1)$ \\
RIR & Trend \& intercept & $-7.215(0)$ & $-3.574^{* * *}$ & $\mathrm{I}(1)$ \\
LAB & Trend \& intercept & $-3.786(0)$ & $-3.574^{* * *}$ & $\mathrm{I}(1)$ \\
GFCF & Trend \& intercept & $-6.166(3)$ & $-3.595^{* * *}$ & $\mathrm{I}(1)$ \\
UN & Trend \& intercept & $-4.659(0)$ & $-3.574^{* * *}$ & $\mathrm{I}(1)$ \\
\hline$*\left[\left[^{* *}\right] /\left(^{* * *}\right)\right.$ denotes significance at 10\%, $/[5 \%] /(1 \%)$, level of significance respectively
\end{tabular}

It is evident from Table 1 and 2 that variables are stationary at both $1 \%, 5 \%$ and $10 \%$ level of significance using trend and intercept. Therefore, the study rejects the null hypothesis of unit root in each of the series and concludes that variables are integrated of the same order I (1).

\section{Results}

Since it is confirmed that variables are integrated of the same order I (1), the study can then proceed assessing the existence of long-run economic equilibrium relationship amongst variables. But then again, it is very essential that the study conduct a lag length selection test to establish the number of lag to employ in the analysis. The results are presented in Table 3 which suggest that all the criterions except the Akaike information criteria (AIC) selected a lag of 1 .

Table 3: selection of lag order criteria

\begin{tabular}{|c|c|c|c|c|c|c|}
\hline Lag & $\log \mathrm{L}$ & LR & FPE & AIC & SIC & HIQ \\
\hline 0 & -257.472 & NA & 2172.326 & 21.873 & 22.118 & 21.938 \\
\hline 1 & -327.623 & NA & 83.334* & 27.009 & $30.026^{*}$ & 27.954* \\
\hline 2 & -250.303 & 69.321 & 89.386 & $26.089 *$ & 32.124 & 27.979 \\
\hline
\end{tabular}

Based on the optimum lag length of one, the Johansen technique is then performed using two test statistics known as Trace and Maximum Eigen-value. These two test statistics assist in evaluating the null hypothesis of 
$\Upsilon=0$ in contrast to the alternatives of $\Upsilon>0,1,2$, or 3 . The Johansen cointegration rank test results are presented Tables 4 and 5 below.

Table 4: Cointegration rank test (Trace test)

\begin{tabular}{llll}
\hline Hypothesized No. of CE(s) & Trace Statistic & 0.05 Critical Value & Prob.** \\
\hline None ${ }^{*}$ & 96.50334 & 95.75366 & 0.0444 \\
At most 1 & 61.00516 & 69.81889 & 0.2058 \\
At most 2 & 35.60699 & 47.85613 & 0.4164 \\
At most 3 & 20.65744 & 29.79707 & 0.3793 \\
At most 4 & 8.979829 & 15.49471 & 0.3672 \\
At most 5 & 2.354730 & 3.841466 & 0.1249 \\
Trace test indicates 1 cointegrating equation(s) at the 0.05 level & \\
${ }^{*}$ denotes rejection of the hypothesis at the 0.05 level & \\
\hline
\end{tabular}

Table 5: Cointegration rank test (Maximum-Eigen test)

\begin{tabular}{llll}
\hline Hypothesized No. of CE(s) & $\begin{array}{l}\text { Max-Eigen } \\
\text { Statistic }\end{array}$ & 0.05 Critical Value & Prob.** \\
\hline None* & 45.49818 & 40.07757 & 0.0300 \\
At most 1 & 25.39817 & 33.87687 & 0.3586 \\
At most 2 & 14.94955 & 27.58434 & 0.7522 \\
At most 3 & 11.67761 & 21.13162 & 0.5797 \\
At most 4 & 6.625100 & 14.26460 & 0.5344 \\
At most 5 & 2.354730 & 3.841466 & 0.1249 \\
Max-eigenvalue test indicates 1 cointegrating equation(s) at the 0.05 level & \\
*denotes rejection of the hypothesis at the 0.05 level & \\
\hline
\end{tabular}

Table 4 (Trace) and Table 5 (Maximum-eigen) both suggest the existence of 1 cointegrating equation at 5 per cent level of significance. Therefore, the study rejects the null hypothesis of $\Upsilon=0$ and concludes that there is a long-run economic equilibrium correlation amongst the variables. To distinguish between the long-run and the short-run influence that the explanatory variables have on the explained variable, the study employed the VECM. The long-run estimation of the selected variables on economic growth in South Africa is presented in Table 6 using the equation 3.

Table 6: Long-run results: GDP

\begin{tabular}{llll}
\hline Variables & Coefficient & Standard Errors & t-statistics \\
& & & \\
\hline BDIF (-1) & -0.214 & 0.054 & -3.964 \\
RIR(-1) & -0.046 & 0.035 & -1.302 \\
LAB(-1) & 0.238 & 0.090 & 2.630 \\
GFCF (-1) & 0.285 & 0.027 & 10.611 \\
UN(-1) & -0.153 & 0.068 & -2.239 \\
\hline
\end{tabular}

The long-run results as shown in Table 6 suggest that there is a negative long-run relationship between BDIF and GDP in South Africa. These results are consistent with the studies conducted by Fatima, Ahmed \& Rehman (2012) and Ezeabasili, Tsegba \& Ezi-Herbert (2012). By implication, the outcomes of this study justify the fact that the economy of South Africa deteriorates predominantly due to budget deficits among other reasons. Furthermore, the results revealed an inverse relationship of RIR and UN towards GDP and a positive relationship of GFCF and LAB towards GDP. All the variables with the exception of RIR are statistically substantial in explaining the explained variables since they have $t$-values greater than two absolutely. The policy consequence of these results is that $1 \%$ increase in BDIF would worsen GDP by $0.21 \%$. Moreover, a $1 \%$ increase in RIR and UN would diminish GDP by $0.05 \%$ and $0.15 \%$ respectively. LAB and GFCF were found to be enhancing economic growth by $0.24 \%$ and $0.29 \%$ respectively. Furthermore, the VECM results confirm the existence of error correction as shown in Table 7 below. The coefficient of the error term 
is -0.29 and statistically substantial with t-value of -2.41 . This suggests that about $29 \%$ of the variation in GDP from its equilibrium level is corrected with a period of a year.

Table 7: Error correction results: RGDP

\begin{tabular}{llll}
\hline Variables & Coefficient & Standard Errors & t-statistics \\
\hline CointEq1 & -0.287 & 0.406 & -2.411 \\
D(GDP(-1)) & -0.149 & 0.354 & -0.423 \\
D(BDIF(-1)) & -0.171 & 0.204 & -0.841 \\
D(RIR(-1)) & -0.345 & 0.188 & -2.830 \\
D(LAB (-1)) & -0.371 & 0.394 & -0.940 \\
D(GFCF(-1)) & -0.019 & 0.067 & -0.278 \\
D(UN(-1)) & -0.230 & 0.189 & -1.219 \\
\hline
\end{tabular}

The diagnostic checks were performed in order to confirm if the model estimated is of good fit. The goodness of the model was tested by employing three techniques namely langrage multiplier (LM) test for serial correlation, Jarque-Bera for normality test and the white test for heteroskedasticity. Results presented in Table 8 suggest that the model estimated is not suffering from serial correlation, the residuals are distributed normally and there is no evidence of conditional heteroskedasticity.

Table 8: Diagnostics tests results

\begin{tabular}{lllll}
\hline Test for: & Test & Null hypothesis & P-value & Conclusion \\
\hline $\begin{array}{l}\text { Breuch-Godfrey Serial } \\
\text { correlation }\end{array}$ & LM test & No serial correlation & 0.437 & Accept $\mathrm{H}_{0}$ \\
$\begin{array}{l}\text { Heteroskedasticity } \\
\text { Normality }\end{array}$ & White & Homoscedasticity & 0.394 & Accept $\mathrm{H}_{0}$ \\
\hline
\end{tabular}

The model was furthermore tested for stability by means of the Inverse Roots of AR Characteristic Polynomial technique. The results presented in figure 2 suggest that all the inverse roots are contained within the unit cycle and are less than 1 . This is a good indication that VAR fulfils the stability condition of the model estimated.

Figure 2: Stability results Inverse Roots of AR Characteristic Polynomial

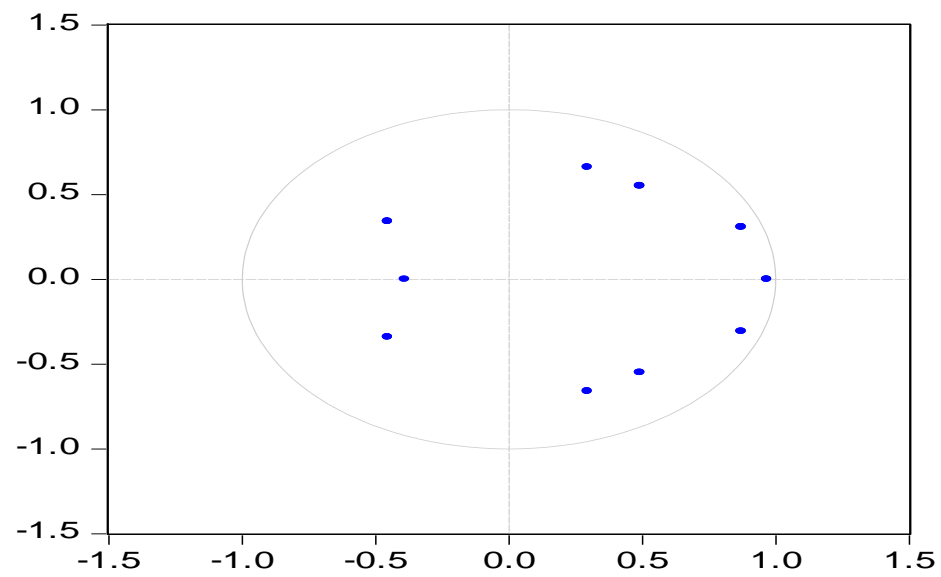

To denote the breakdown of the forecasted error variance for a specific time distance, the study employed the Variance Decomposition. Unambiguously, the Variance Decomposition splits the discrepancy in an endogenous variable into the component shocks to the VECM. The Variance Decomposition results are presented in table 9. 
Table 9: Variance Decomposition results: GDP

\begin{tabular}{llllllll}
\hline Period & S.E. & GDP & BDIF & RIR & LAB & GFCF & UN \\
\hline 1 & 1.592204 & 100.0000 & 0.000000 & 0.000000 & 0.000000 & 0.000000 & 0.000000 \\
2 & 2.275472 & 76.63155 & 5.116885 & 13.03147 & 2.877831 & 0.270964 & 2.071295 \\
3 & 2.706356 & 64.32098 & 7.544030 & 23.18199 & 3.259627 & 0.191692 & 1.501675 \\
4 & 2.965966 & 58.66716 & 10.90624 & 25.07187 & 3.609359 & 0.272342 & 1.473028 \\
5 & 3.153743 & 56.36553 & 13.20223 & 24.42105 & 4.363728 & 0.292476 & 1.354995 \\
6 & 3.344279 & 56.18206 & 13.83730 & 23.55084 & 4.952699 & 0.260203 & 1.216909 \\
7 & 3.562731 & 56.21723 & 13.82003 & 23.39119 & 5.202530 & 0.240440 & 1.128586 \\
8 & 3.781891 & 55.50901 & 13.93888 & 24.01840 & 5.289202 & 0.218400 & 1.026114 \\
9 & 3.977382 & 54.50027 & 14.36898 & 24.63080 & 5.373942 & 0.197747 & 0.928259 \\
10 & 4.149264 & 53.71825 & 14.88924 & 24.84260 & 5.511549 & 0.184865 & 0.853492 \\
\hline
\end{tabular}

Cholesky ordering: RGDP, BDIF, RIR, LAB, GFCF, UN

Table 9 presents the comparative implication of respective structural shock to the variables in the system. The study reports the variance decomposition of GDP over a 10 years period. In the first period, 100\% of GDP variances can be explained by its own innovation. It is also evident that as time goes by; its contributions are gradually reducing until it reaches $53.7 \%$ in the last year which is still the highest contribution as compared to the other variables. This brings to a conclusion that over 5 years ahead, GDP discrepancies can be described by its own shocks. Following GDP itself, the $2^{\text {nd }}$ up to the $8^{\text {th }}$ period reveal the significance of BDIF, RIR, LAB, GFCF and UN in explaining the variation of GDP. It is evident that from the second year, BDIF accounts for $5.1 \%$ in the variation of GDP, RIR accounts for $13 \%$ while LAB, GFCF and UN accounts for $2.9 \%$, $0.3 \%$ and $2.1 \%$ respectively. Based on the analysis, the GDP is mainly influenced by RIR and BDIF. The results obtained undoubtedly associate discrepancies in the level of GDP in South Africa to be explained by the contributions of real interest rate, budget deficit and labour.

The study further applied the General Impulsive Response Function to trace the consequence of one-time shock to one of the innovations on the present and forthcoming values of the endogenous variables. In other words, the General Impulse Response Function (GRIF) demonstrates the effects of shocks on the adjustment path of the variables. This study employed the GIRF as proposed by Pesaran and Shin (1998) as a replacement to the simple Impulse Response Function (IRF) mainly due to its numerous shortcomings. The GIRF over the 10 years for the VECM estimation is shown in Appendix 1. In this study, the response of GDP to a shock in itself is positive over the period of the study. Moreover, Appendix 1 suggests that the response of GDP to shocks from BDIF is positive in the first two years. Subsequently, the response of GDP is seen to be negative which permits the study to justify the decrease in the economic growth of South Africa due to budget deficits. This response is as anticipated in the neoclassical theory which substantiates that increase in budget deficits will result in reduction of economic growth. The conclusion of the GIRF reveals that an adjustment in the level of GDP will cause BDIF, RIR, LAB and UN to respond negatively through all the years.

\section{Conclusion and Recommendations}

This study was undertaken to examine the nature of the relationship between the budget deficits and economic growth in South Africa. To answer this question, this study adopted the VECM procedures using annual data covering the period 1985 to 2015. The Johansen cointegration test confirmed the existence of 1 cointegrating equation between the variables employed. Furthermore, the VECM results showed a negative relationship between budget deficits and economic growth in South Africa. This implies that increase in budget deficits would lead to reduction in economic growth. These results are consistent with the neoclassical hypothesis that suggested that budget deficits are detrimental towards growth and development of a country. The error correction results revealed that there is a convergence towards steadiness in the longrun although the adjustment is weak at $29 \%$ per annum. The diagnostic checks validated the model estimated. The Variance Decomposition and General Impulsive Response Function were also employed to assess the responsiveness of GDP towards shocks coming from the selected variables. Since it was found that budget deficits are detrimental to economic growth of South Africa, the government should put much emphasis on strengthening policies such as fiscal consolidation and austerity measures across all government 
departments and state owned entities. Furthermore, the government must apply expenditure ceiling and improve the taxation system to find a balance between government expenditure and revenue collected. The government of South Africa should also work hand in hand with private sectors, labourers and other stake holders to create efficient environment that will promote economic growth.

\section{References}

Aslam, A. L. M. (2016). Budget Deficit and Economic Growth in Sri Lanka: An Econometric Dynamic Analysis. World Scientific News, 46: 176-188.

Barro, R. J. (1989). The Ricardian Approach to Budget Deficits. Journal of Economic Perspective, 3(2): 55-72.

Biza, R.A, Kapingura, F.M \& Tsegaye, A. (2015). Do budget deficits crowd out private investment? An analysis of the South African economy. International Journal of Economic Policy in Emerging Economies, 8(1): 52-76.

Bonga-Bonga, L. (2011). Budget Deficit and Long-Term Interest Rate in South Africa. African Journal of Business Management, 6: 3954-3961.

Diamond, P. A. (1965). National Debt in a Neoclassical Growth Model. The American Economic Review, 55(5): 1126-115.

Eminer, F. (2015). The Impact of Budget Deficit on Economic Growth in North Cyprus. WEI International Academic Conference Proceedings, Vienna: Austria.

Ezeabasili, V.N., Tsegba, I. N. \& Ezi-Herbert, W. (2012). Economic Growth and Fiscal Deficits: Empirical Evidence from Nigeria. Economic and finance Review, 2(6): 85-96.

Fatima, G., Ahmed, M. \& Rehman, W. (2012). Consequential Effect of Budget Deficit on Economic Growth of Pakistan. International Journal of Business and Social Science, 3(7): 203-208.

Hubbard, R.G. \& Judd, K.L. (1986).Liquidity Constraints, Fiscal Policy, and Consumption. Brookings Papers on Economic Activity, 1: 1-51.

Johansen, S. (1991). Estimation and Hypothesis Testing of Co-integration Vectors in Gaussian Vector Autoregressive Models. Econometrica, 59: 1551-1580.

Johansen, S. (1995). Likelihood-Based Inference in Cointegration Vector Auto-Regressive Models. Oxford: Oxford University Press.

Keynes, J.M. (1936). The General Theory of Interest, Employment and Money, London: Macmillan.

Kotlikoff, L.J. (1986). "Budget Delusion". The Public Interest, 84: 53-65.

Mashakada, T.L.J. (2013). Macroeconomic Consequences of Fiscal Deficit in Developing Countries: A Comparative Study of Zimbabwe and Selected African Countries (1980-2008): (unpublished PhD Thesis, Stellenbosch University, 2013).

Mujuta, S.C. (2013). The Effectiveness of Fiscal Deficit in Stimulating Economic Growth: (unpublished Masters Dissertation, University of Western Cape, 2013).

Murwirapachena, G, Maredza, A \& Choga, I. (2013). The Economic Determinants of Budget Deficit in South Africa. Mediterranean Journal of Social Sciences, 4(13): 561-569.

National Treasury. (2011). National Budget Review. [Online] available from http://www.treasury.gov.za/documents/nationalbudgetreview [25 February 2015]

National Treasury. (2015). National Budget Review. [Online] available from http://www.treasury.gov.za/documents/nationalbudgetreview [25 February 2015]

Odhiambo, O.S, Momanyi, G., Lucas, O. \& Aila, F.O. (2013). The Relationship between Fiscal Deficit and Economic Growth in Kenya: An Empirical Investigation. Greener Journal of Social Sciences, 3(6): 306323.

Pesaran, M. H., \& Shin, Y. (1998). Generalized Impulse Response Analysis in Linear Multivariate Models. Economic Letters, 58(1), 7-29.

South African Reserve Bank (2015). Statistical query (historical macroeconomic time series information). 


\section{Appendixes}

\section{Appendix 1: The General Impulsive Response Function}
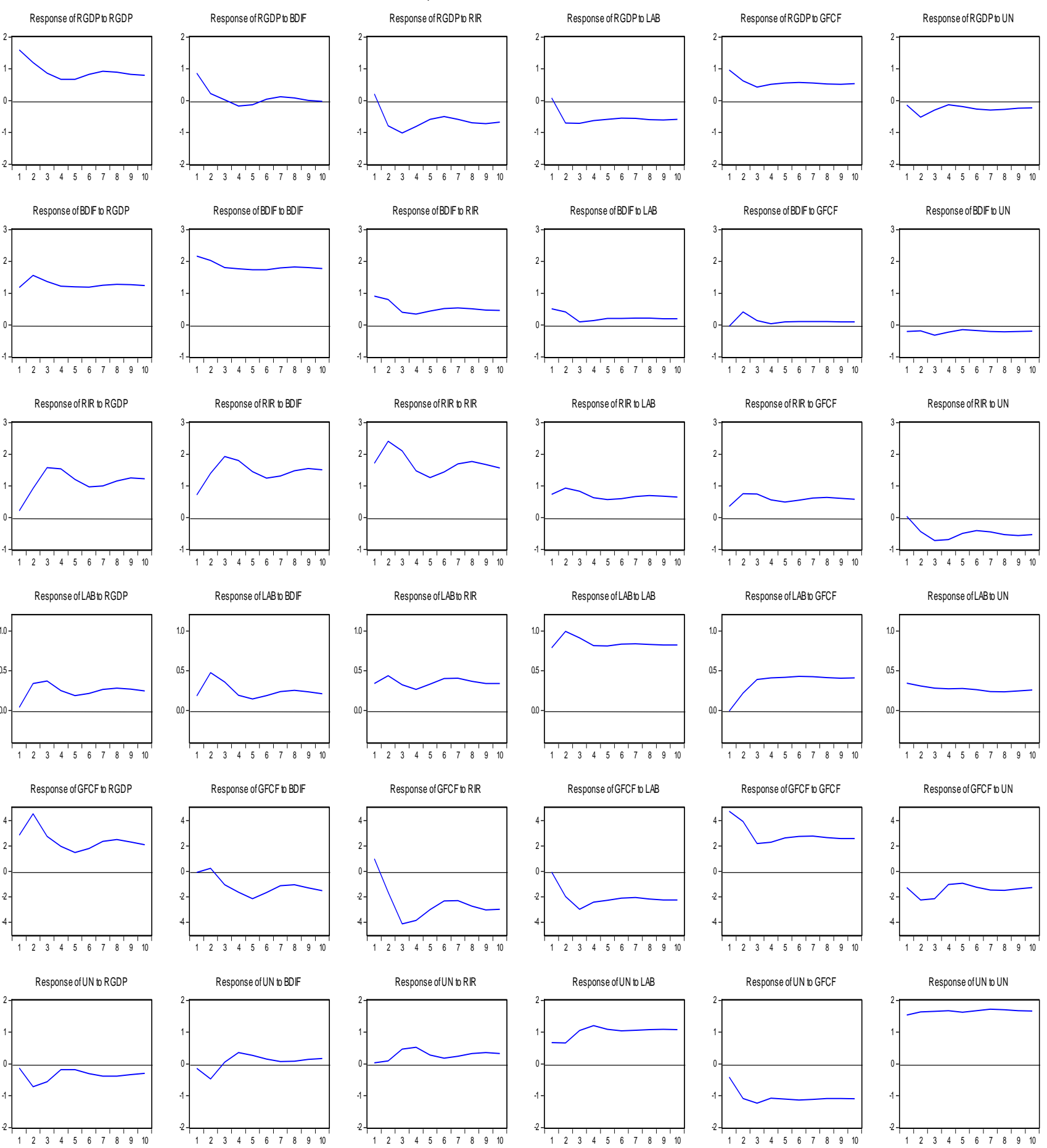